\title{
Intensive Horticulture in Almería (Spain): A Counterpoint to Current European Rural Policy Strategies
}

\author{
JOSÉ A. AZNAR-SÁNCHEZ, EMILIO GALDEANO-GÓMEZ AND \\ JUAN C. PÉREZ-MESA
}

\begin{abstract}
Much of the recently published literature in Europe on rural development tends to focus on de-agrarianization and multifunctionality in rural livelihoods as a way to generate employment and incomes. This paper analyses the case of Almería (Spain), an exception to this general rule. Almería, once one of the poorest Spanish provinces, has become the most affluent province in Andalusia and ranks now about average in Spain. This fast growth rate was achieved thanks to the development of intensive horticulture and its processes of change from the 1970s to the present day, due to the factors reviewed in the present study. This success story is a counterpoint to current European rural development strategies that consider the promotion of agriculture a mistake and advocate instead the economic diversification of farms.
\end{abstract}

Keywords: rural development, Europe, agriculture, intensive horticulture, Almería

\section{INTRODUCTION}

Over recent decades, the guidelines of socio-economic policies and regional development, particularly in the rural areas of Europe, have been marked by a restructuring of the agrarian sector. These guidelines have meant the progressive loss of importance of the agricultural sector, both in terms of the surface area cultivated and the workforce employed, and the reorientation of farms and the multifunctionality of agrarian activities. Despite being recognized as a multifunctional activity (van Huylenbroeck and Duran 2003; Brouwer 2004), farming is tending to become less agrarian, since the orientation of multifunctionality is more territorial than sectoral (Potter 2004). Thus, economic growth has been associated with phenomena of productive diversification and consumption (tourism, leisure, typical local products, nature conservation etc.), in which agriculture is no longer the driving force behind the economy (van der Ploeg et al. 2000).

Although some authors (Knickel and Renting 2000; Marsden et al. 2002) have shown that development based on farming generates diverse economic activities, the overall trend is to identify the minor role of the agrarian sector in stimulating economic growth in rural regions (Terluin and Post 2000; Dwyer et al. 2002; Terluin 2003; Bryden and Hart 2004). On the whole, however, it is accepted that the nature of rural areas and the challenges they face vary considerably across Europe, and as a result what is understood to constitute development

José A. Aznar-Sánchez, Emilio Galdeano-Gómez and Juan C. Pérez-Mesa, Departamento de Economía Aplicada, Universidad de Almería, La Cañada de San Urbano, s/n, 04120 Almería, Spain. E-mails: jaznar@ual.es; galdeano@ ual.es; juancarl@ual.es

This research was partially funded by Spanish MCINN and FEDER aid ECO2008-02258.

The authors would like to thank Carlos Oya, the editors of JOAC and the anonymous referees for their helpful comments on the earlier drafts of this paper. 


\section{José A. Aznar-Sánchez, Emilio Galdeano-Gómez and Juan C. Pérez-Mesa}

strategies and rural policies also varies (Baldock et al. 2001; Garzon 2005). These facts also lead us to consider that a certain stage of regional development is dependent upon the region's history and singularities (Hassapoyannes et al. 1998; Suchacek and Malinovsky 2007), which implies the need for more empirical evidence on this issue (Buchenrieder et al. 2007).

This study takes as reference the paradigmatic economic growth of Almería province in Spain, whose agricultural and economic development has taken place without the support of any regional policy. ${ }^{1}$ The development of Almería's economy is described by Mota et al. (1996) as 'Almería's economic miracle'. This province ranked fiftieth out of a total of 51 Spanish provinces as regards per capita GDP (Gross Domestic Product) in 1969, but its position had improved to 24th by 2006, and between 1994 and 2005 Almería's growth in GDP nearly quadrupled relative to the regional and national averages (INE 2008). This growth has been driven by intensive agriculture of horticultural products and the marketing services and related auxiliary industry, which have benefited growers of all sizes and all sectors of the economy. As Tout $(1990,304)$ states: 'A horticultural revolution has occurred in parts of the province of Almería in the last 20 years, as formerly barren lands have been turned into extremely productive family-run farms'. Recently, Downward and Taylor $(2007,281)$ quote the following description made by Almería's Director of Agriculture:'This is the most social level of agriculture in the world, not even the best communist system would have achieved what has been achieved in Almería . . . and for people who maybe 50 years ago would have only had a herd of goats.'

The credentials of intensive farming in Almería are outstanding. The land area dedicated to intensive agriculture in greenhouses $(26,750 \mathrm{ha})$ represents over half of the national total. More than 70 per cent of this area is concentrated in the zone known as 'El Poniente', the largest concentrated area of intensive agriculture in the world (UNEP 2005, 200-1). In 2008, agricultural production increased to 2.95 million tons and turnover reached 1,463 million euros, making Almería the top vegetable-growing province in Spain. Over half the produce is destined for foreign markets, and the corresponding 1.66 million tons that are exported make this province the largest Spanish exporter of fresh vegetable produce and create a surplus in its trade figures every year.

Its social importance is also extremely relevant as the sector was founded on a system of family farms and has been a key source of employment. The farmland is widely divided among 13,500 small-scale farmers and the sector provides direct employment to more than 40,000 workers annually. The family nature of the farms and their reduced size in terms of land use were characteristics that appeared at the beginning of the sector's development but have endured until the present day, making them the most characteristic and unique traits (GarcíaLatorre et al. 2001; Downward and Taylor 2007).

The objective of this paper is to show that the economic development of Almería constitutes an exceptional case in European rural agriculture, since it can be explained by the successful agrarian activity. In addition, this study also attempts to provide arguments to reflect on the rural development strategies applied in Europe in recent decades, and to complete the existing gaps in empirical analyses in the European context on this issue.

The rest of the paper is organized as follows. The second section describes the agricultural sector's role in rural development in Europe. The third section presents the case study of the agriculture-based development in Almería, analysing this sector's contribution to the province's economic growth, the factors that brought it about, the territorial and environmental

1 These features are probably the reason behind the lack of regional case studies on this area, as most research works focus on the requirements and recommendations for European rural policy. 


\section{Intensive Horticulture in Almería (Spain): A Counterpoint}

dimensions, productive and labour organization, marketing, technological innovation and the formation of an agro-industrial cluster. Finally, the fourth section outlines the conclusions.

\section{AGRICULTURAL VERSUS RURAL DEVELOPMENT IN EUROPE}

Although agriculture remains the predominant land use in rural Europe, it no longer dominates socially or economically. In the European Union (EU), the sector accounts for only 6 per cent of employment and even plays a minor role in rural employment and the GDP (Gross Domestic Product) of rural regions, ${ }^{2}$ despite the slight increase due to the recent extension of the Union to include 27 member countries; for example, 4.9 per cent of employment in the EU-25, as compared to 3.7 per cent in the EU-15 (European Commission 2007a).

Whereas agriculture remains a strategically significant policy sector and is the major force determining the rural environment, most rural areas rely to a diminishing extent on farming. As rural areas have come to fulfil other functions, so other public policies (apart from agriculture) have impinged on rural areas and governments have been drawn in to resolve issues concerning social and economic development in rural areas through rural development policy. However, the nature of rural areas and the challenges they face vary considerably across Europe, and consequently what is understood to constitute rural development policy also varies (see, e.g., Baldock et al. 2001; Bryden 2003; Garzon 2005). As a deliberate focus of activity, rural development policy has emerged as a counterpoint to, and in the intersection between, two other established fields: agricultural policy and spatial policy (Ward et al. 2005).

As far as agrarian-based development is concerned, farmers' interests are equivalent to rural interest, multifunctionality of rural areas is a historical outcome of traditional farming, and viable rural areas depend upon farming activity both economically and culturally. On the other hand, the perception of rural development is much wider: local actors represent a broad range of interests according to their social affiliation and economic status; the multifunctionality of rural areas is due to internal diversity and external pressures; and a competitive farming sector is not always a prerequisite for viable rural areas (Baldock et al. 2001; Potter 2004; Ward et al. 2005). ${ }^{3}$

Despite the existing heterogeneity, the most accepted trend over the last two or three decades in European rural development policy, under the predominant conception of a model of endogenous development (e.g. the LEADER programme), has been to promote increasing diversification in order to accommodate various economic activities and new lifestyles. In fact, the encouragement of diversification of economic activities is one of the three major objectives established to govern the EU rural development policy for the period 2007-13 (Council Regulation 2005). This is based on the argument that every region or locality should develop by taking advantage of an existing or potential local comparative advantage that may lie anywhere within the spectrum of economic activities. Activities such as organic farming, maintenance of landscape, tourism, energy harvesting and employment creation through labour-intensive services should be promoted (Pausewang 1995). In many cases the focus based on agriculture as the main activity has been considered misleading (e.g. Terluin 2003). The fact of the inexorable decline in primary-sector employment and the depopulation of rural areas, particularly in many parts of southern Europe and the remoter mountainous regions of central and northern Europe, probably constitute the main reason for the described political orientation (Ward et al. 2005).

2 The combined agricultural and food sector represented only 4.3 per cent of GDP in the EU-27 in 2006.

Therefore, although the initial formulation of multifunctionality in Europe, in the early 1990s, referred mainly to agriculture and farming activities, it has tended towards the concept of multifunctionality of rural areas in which agriculture may be absent (Losch 2004, 338-40). 


\section{José A. Aznar-Sánchez, Emilio Galdeano-Gómez and Juan C. Pérez-Mesa}

Nevertheless, some agriculture-based regions continue to show a self-sustained process of growth (European Commission 2007b). For example, authors such as Hassapoyannes et al. (1998) state that this is the case of agricultural development models in regions of Greece, Italy, Holland or Spain, which are based on a series of comparative advantages that sustain an endogenous development. In Italy, food chains have been the starting point for quality improvement in meat, wine and tobacco production. In the case of Spain, it has been the cooperative basis (small farmers) and marketing strategies. In Greece, the agricultural sector is characterized by the persistence of traditional relations in production, such as family farming and diversification. In Holland, the focus was on the social organization of the production process and marketing strategies. However, these authors describe these examples of competitive agriculture as a component to bear in mind rather than a basis on which rural development can be generalized.

Nonetheless, the role of the agricultural sector and rural development policy in stimulating economic growth in rural regions constitutes an issue of debate in the formulation of development models (Lowe et al. 1993; Cloke 1997; Ray 2001; Terluin 2003).

\section{THE CASE STUDY OF THE AGRICULTURAL-BASED DEVELOPMENT OF ALMERÍA}

A case-study methodology is selected for this study, as it allows an understanding of the evolution of this regional development at a deeper level (Yin 1989). We use a retrospective analysis based on research work that focused on some components of this economic development and secondary statistical data. In the following subsection, a general historical overview is provided, outlining the main features of Almería's economic development and analysing the specific role of the agricultural sector. The analysis then goes on to present factors that influenced the boom in this sector, paying particular attention to the territorial, environmental, productive, labour, marketing and technological aspects. The final subsection deals with the agro-industrial cluster that has been built up around the production and marketing of vegetables. In addition, although this case study essentially reflects a perspective within agricultural economics and debates on EU development policies, some aspects of this phenomenon will also be reviewed in a wider context, namely with reference to the 'food regimes' (e.g. Friedmann 2005; McMichael 2009).

\section{The Role of Agriculture in Almería's Economic Development}

The province of Almería has experienced an unprecedented transformation in terms of Spain's recent economic history. Until the end of the 1960s, all of the social and economic indicators characterized Almería as a province that was underdeveloped and in a stage of decline. However, since then Almeria's economy has begun a period of sustained economic growth, which has resulted in development indicators eventually superior to the regional and national averages. The turning point in the province's process of economic growth took place in the 1970s with the boom in intensive horticulture. From that moment on, Almería's economic growth surpassed the national average, constituting one of the most outstanding examples of convergence in the second half of the twentieth century. ${ }^{4}$ Almería, once one of the worst-ranked provinces in Spain in terms of GDP, has become the first province in Andalusia

4 We should highlight the fact that this process of convergence of the provincial and national economy has taken place over the period of greatest growth of the Spanish economy in recent history. 
Figure 1 Per capita GDP in Almería in comparison to Spain and Andalusia, from 1955 to 2005 (per cent)

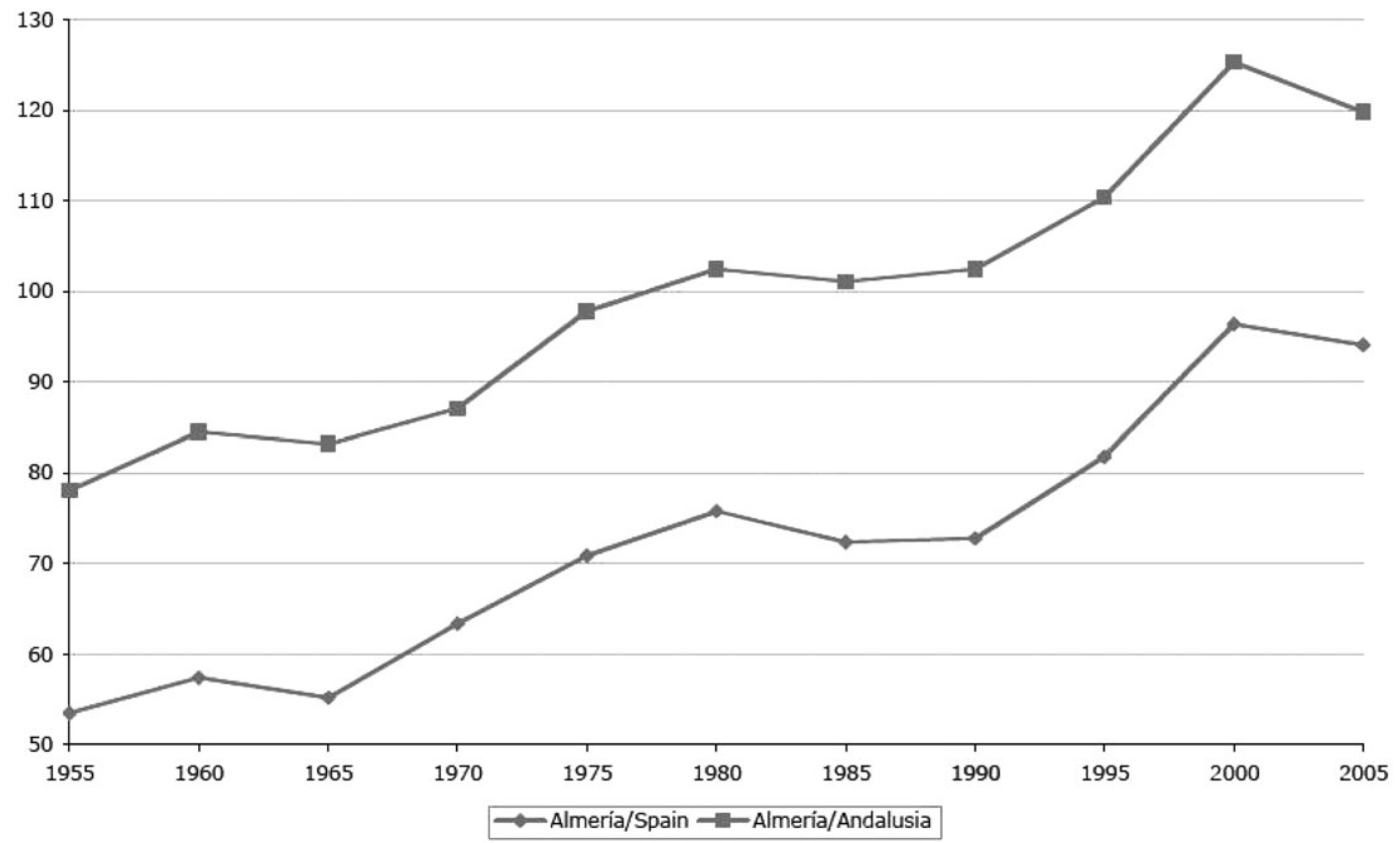

Source: Instituto Nacional de Estadística (INE) and the authors.

(southern Spain) and has reached an intermediate position nationally, after gaining 30 percentage points with respect to the national average (Figure 1). Furthermore, this process of convergence has taken place despite a substantial increase in population. Indeed, the population of the province has grown in the past years as never before, making it the province in Spain with the second-highest population growth in the last three decades, and reversing its longterm tradition as a province of emigrants to become a significant destination for immigrants. ${ }^{5}$ Indeed, Almería is the second Spanish province in terms of percentage of foreign-born residents (19.7 per cent in 2008).

From a sectorial point of view, the importance of the agricultural sector in the productive structure of Almería province in the 1970s has practically been maintained to the present day (Table 1). Over this period the relevance of the agricultural sector in Almería's production has only fallen by 5.5 percentage points, maintaining a contribution that is three times that of the regional average, and nearly six times greater than the national average. Therefore, the general downward trend in the importance of the agricultural sector has been much less marked in Almería, which has actually intensified its agricultural specialization. Indeed, the index of agricultural specialization grew considerably from 1969 to 1979, maintaining very high levels

5 Since 1970, the population growth in Almería has been far greater than that of Andalusia and Spain. The cumulative annual rate of growth in the province's population has been 1.51 , as opposed to 0.83 and 0.80 for the regional and national level, respectively. The magnitude of this growth has been much more marked since the mid-1990s, with the arrival of large-scale immigration. Thus, from 1995 to 2008 the provincial rate was 2.45, as opposed to 0.97 and 1.17 in Andalusia and Spain, respectively (INE 2009). 


\section{José A. Aznar-Sánchez, Emilio Galdeano-Gómez and Juan C. Pérez-Mesa}

Table 1. The production structure for Almería, Andalusia and Spain in 1970 and 2006 (per cent GDP)

\begin{tabular}{|c|c|c|c|c|c|c|}
\hline & \multicolumn{3}{|c|}{1970} & \multicolumn{3}{|c|}{2006} \\
\hline & Almería & Andalusia & Spain & Almería & Andalusia & Spain \\
\hline Agriculture & 29.1 & 19.7 & 12.8 & 23.5 & 7.8 & 4.0 \\
\hline Industry & 13.8 & 21.7 & 30.9 & 8.0 & 13.7 & 20.2 \\
\hline Construction & 9.2 & 8.9 & 7.8 & 10.4 & 12.2 & 10.0 \\
\hline Services & 47.9 & 49.7 & 48.5 & 58.1 & 66.3 & 65.8 \\
\hline Total & 100.0 & 100.0 & 100.0 & 100.0 & 100.0 & 100.0 \\
\hline
\end{tabular}

Source: Instituto Nacional de Estadística (INE), several years.

Figure 2 The GDP specialization index in Almería compared to the Spanish average, from 1959 to 2005

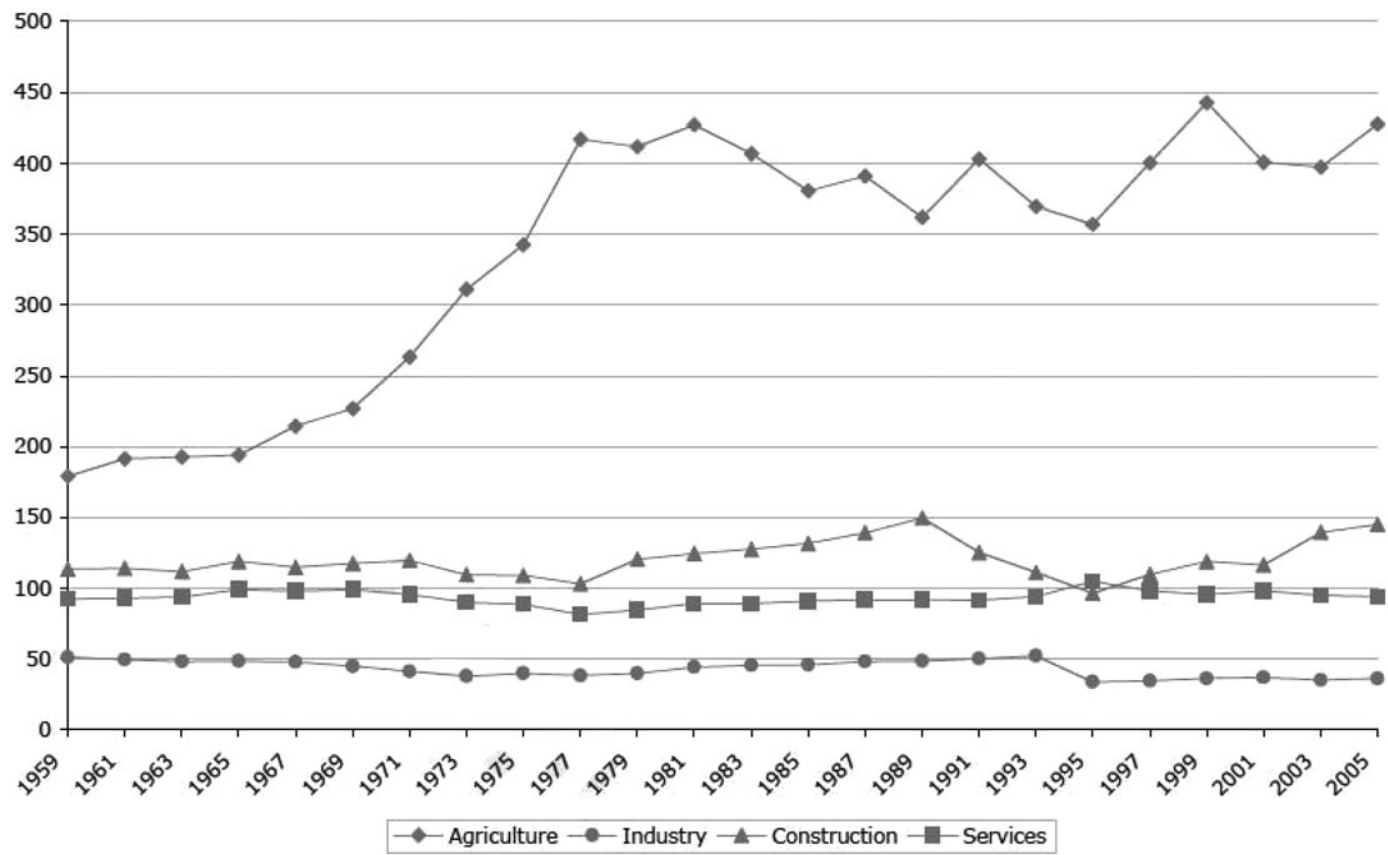

Source: Instituto Nacional de Estadística (INE) and the authors.

thereafter (Figure 2). As a result, Almeria's share of regional (Andalusia) and national (Spain) agricultural output has increased over time, from 8.6 per cent of the regional total in 1970 to 28.2 per cent in 2006, and from 1.8 per cent of Spain's total in 1970 to 7.5 per cent in 2006.

Therefore, over the period in question, agricultural development has played an important role in the economic boom in Almería. In this respect, the study of Ferraro (2000, 44-9) highlights the considerable contribution of the agricultural sector to the economic growth of the province, calculating that 30-35 per cent of the increase in the province's GDP between 1967 and 1995 was due to this sector. That calculation only considered the direct effects of 


\section{Intensive Horticulture in Almería (Spain): A Counterpoint}

agriculture, without including the indirect effects through the cluster of industrial activities and services (marketing, handling, packaging, research etc.) linked to the sector, which would have increased its relevance even more. Indeed, this cluster of activities linked to agriculture accounts for around 32 per cent of the province's GDP (Ferraro and Aznar 2008, 371-2). These aspects will be dealt with greater detail in the final part of this section.

\section{Factors Influencing the Boom in Intensive Horticulture}

Almería's intensive farming represents the largest agrarian transformation that Spain has experienced in recent decades. When trying to explain the process that led to the emergence of this sector, it becomes difficult to find similarities with the development of other dynamic farming regions (Tout 1990; Mota et al. 1996; Downward and Taylor 2007). Consequently, this phenomenon has been dubbed the 'Almería miracle'. Nevertheless, instead of considering it as a 'miraculous' paradigm, we should take into account a collection of social, institutional, economic and technological factors that have combined to give rise to this process.

The natural conditions of this province were ideal for the growing of off-season precocious horticultural crops under plastic, since the benign climatic conditions and the high number of hours of sunlight permitted farming during times of the year when it was not possible in other European farming areas. In addition, low and erratic rainfall was compensated by the abundance of underground water resources. However, in order to take advantage of these natural assets, the contribution of an exogenous and institutional component was necessary. This came in the form of federal intervention via the National Colonization Institute (INC, in Spanish). In this way, access to underground aquifers was made possible thanks largely to institutional actions in the 1950s, which promoted the use of the technology necessary for extracting this resource. Moreover, the intervention of the INC was not only limited to providing infrastructure for water and electricity; it also encouraged new people to settle in the area and offered them technical and financial advice. Its actions proved to be decisive with regard to the social composition of the new sector, as the allocation of small-scale plots of land (3.5 ha) among settlers set the foundations for a relatively small scale-farm model that has lasted until the present day (García-Latorre et al. 2001).

In addition to this institutional component, the human factor played a fundamental role in the sector's initial phase. The INC's work to settle the area was accompanied by a widespread response from families from nearby rural areas in times of crisis, who were attracted by the proposition of easy access to land and the possibility of obtaining their own property, not to mention the high profitability that these farms offered in comparison with traditional agriculture. With their strong work ethic and initiative, these families assumed the risk of farming on completely un-irrigated soil by means of new technological innovations that they put into practice and perfected with great ease, allowing them to increase output and obtain significant profits.

The technological component also made a fundamental contribution during the sector's first phase. At that time, local innovations were developed and subsequently incorporated very rapidly by the majority of farmers. The first step forward took place with the introduction of the farming technique called 'enarenado' (i.e. sandy soil, which is most appropriate for horticulture as it drains well), which completely transformed unproductive lands into prosperous farms with higher yields and a greater degree of precocity (Tout 1990). Later, people began to construct the first plastic greenhouses, intended to provide effective protection against winds and low winter temperatures. This further contributed to increased yields, precocity, quality and water conservation (Galdeano and De Pablo 1999). 


\section{José A. Aznar-Sánchez, Emilio Galdeano-Gómez and Juan C. Pérez-Mesa}

Finally, the favourable conditions of international markets provided an additional exogenous boost that helped to fuel the sector. During a time of growing open trade in the European market, the development of Almería's agriculture benefited from an expanding market for horticultural produce in general ${ }^{6}$ and, in particular, for off-season produce (Pérez-Mesa 2007). This growing demand created incentives for yield increases and was the main reason for continued investment and farm development.

It is important to underline the fact that this continued investment was accompanied by the endogenous development of private financing structures and mechanisms for family-run firms. The private credit facilities offered by marketing firms, and particularly the rising importance of local credit agencies, mainly the Caja Rural de Almería (now Caja Rural Intermediterránea, Cajamar) in the 1960s as an agricultural credit cooperative (with a high degree of participation in the capital from local farmers), were fundamental for continued investment, given the lack of Spanish government support and of foreign investment. ${ }^{7}$

It was upon the above-mentioned foundations that Almería's intensive farming model developed over the course of the 1960s and 1970s. However, its consolidation took place in the 1980s and 1990s, fundamentally based on other endogenous factors, with constant improvement in the fields of production and marketing.

\section{The Territorial and Environmental Dimensions}

The provincial land area dedicated to horticultural greenhouse farming has undergone spectacular growth over the last 30 years, increasing from barely 3,000 ha in 1975 to around 27,000 ha in 2008. This figure makes Almería the Spanish province with the largest area of greenhouse crops, representing more than half of the total area of greenhouses in Spain. This is even more significant considering that it is the country with most hectares dedicated to greenhouse farming in the whole Mediterranean basin, surpassing Italy, Turkey, Morocco, France and Israel. ${ }^{8}$ Furthermore, it is important to bear in mind that the majority of the greenhouse area in this province is actually concentrated in a particular zone in the south-west of the province, known as 'El Poniente'. In this area, of about 27,000 ha, there is a concentration of over 16,000 ha of greenhouses, making it the most important centre of intensive farming in the world. The result is the emergence of an remarkable 'sea of plastic', visible from kilometres away, which has become an outstanding worldwide reference as one of the greatest territorial transformations to have taken place in the last third of the twentieth century. In fact, the concentration of greenhouses in 'El Poniente' is one of the few man-made structures visible from space (UNEP 2005, 200-1). Moreover, the largest greenhouse area in the world seems to have had a positive impact in the struggle to combat climate change. ${ }^{9}$

\footnotetext{
6 The expansion of supermarkets in the late 1980s and the changes in consumers' dietary habits in developed regions such as Europe (Galdeano 2005) have favoured certain agricultural export sectors, particularly that of fresh fruit and vegetables (McMichael 2009).

7 This structure of local financing has constituted another feature that has facilitated the preservation of family ownership structures and decision-making in Almeria's horticultural sector. Therefore, unlike what has occurred to a great extent in other European agricultural sectors, as described by Friedmann (1987) and Friedmann and McMichael (1989), particularly in their description of 'the second food regime', in the present case we find a food sector that has not been developed on the basis of subsidies and that has maintained its structure of small farms rather than large corporate agribusinesses, which in other sectors have generally replaced smallholdings.

8 In 2005 there were 53,800 ha of greenhouses in Spain, 28,000 ha in Italy, 21,800 in Turkey, 17,500 in Morocco, 9,200 in France and 6,200 in Israel (Cotec 2009, 14-16).

The existence of greenhouses in the province of Almería has had a positive effect of both $\mathrm{CO}_{2}$ reduction (as it is absorbed by crops) and in decreasing the local temperature, acting as a brake on atmospheric warming. According to Campra et al. (2008), the 'albedo' (whiteness) effect generated by the plastic greenhouse covering
} 


\section{Intensive Horticulture in Almería (Spain): A Counterpoint}

Nevertheless, the fast development of this sector also brought about challenges and some negative effects. In its initial stage, in the 1970s and 1980s, intensive horticulture was developed without any type of territorial planning and organization. The rapid growth of this sector took place in a very disorderly and unstructured fashion, generating some negative externalities. For too long, the main objective of the farmer was to increase productivity, focusing attention on what occurs inside the greenhouse without worrying about what is going on around it. This behaviour, together with the lack of regulatory norms and public intervention to order the rural space, led to the appearance of environmental and territorial effects, which caused negative externalities for the farmers themselves and for other production activities (Ferraro 2000, 356-7). Among these we should highlight the overexploitation and contamination of aquifers, the extraction of sand and vegetable soils for agricultural use, uncontrolled dumping of waste (organic, plastic, packaging etc.), occupation of areas of environmental interest and landscape degradation, deficiencies in the road network, the invasion of the public hydraulic domain and the poor structure and functioning of the territorial system (Gómez 2003, 85-133). Additionally, the development of intensive agriculture has meant competition for natural resources with other economic activities such as tourism. ${ }^{10}$

Among the restrictions on the development of Almería's intensive agriculture, the hydrological factor has been the one that has been highlighted as the most important, due to both the shortage and the quality of the water. Indeed, although major progress has been made in productivity per cubic metre, the uncontrolled expansion of the surface area dedicated to greenhouses over the 1980s and 1990s exerted great pressure on water supply, which is difficult to quantify due to its mainly subterranean origin. This pressure became manifest as unmistakable symptoms of degradation appeared in the aquifers, such as the progressive salinization in the areas closest to the shore (Tout 1990; Consejería de Agricultura y Medio Ambiente 1991). The solution to this problem (of serious environmental and socio-economic consequence) began to be introduced at the end of the 1980s in the form of generalized systems of water savings (drip irrigation, hydroponics etc.) ${ }^{11}$ and increasing supply (desalinization plants, reservoirs, reusage), together with innovations in studies of the capacity and evolution of the aquifers, with the aim of establishing a suitable framework to regulate demand (Ferraro 2000; Downward and Taylor 2007; Galdeano-Gómez et al. 2008). ${ }^{12}$

The other negative externalities began to be corrected from the late 1980s. The uncontrolled extraction of sand and vegetable soils has all but disappeared thanks to a system of sanctions,

reduced temperatures in the Almería 'Poniente' region by 0.75 degrees from 1983 to 2006. According to their data of SWRF (surface shortwave radiative forcing) and local temperatures trends, the recent development of greenhouse horticulture in this area may have masked local warming signals associated with the increase of greenhouse gases.

10 This would be the case of the towns of El Ejido and Roquetas de Mar, home to the greatest concentration of greenhouses and growing tourist activity, which compete for the use of territory and resources such as water. Nevertheless, it is noted that tourism consumes more water than horticulture, since the latter employs systems and technologies that permit economy of water resources (Galdeano et al. 2008). Also, we should mention the option of agrotourism, which has been considered by some tourism firms recently; that is, guided visits to greenhouses, to become familiar with the type of family farms (see, e.g., http://www.clisol.com/).

11 Almería is Spain's most technologically advanced and efficient irrigation area, with widespread use of drip irrigation systems. As a result, the income generated per cubic metre of water in the greenhouses of Almería is almost eightfold that obtained in olive groves and sixfold that generated on average by irrigation nationwide (Colino and Martínez 2002, 203-5).

12 Legislation has been primordial in the application of these systems: for example, Decree 117/1984 and Law 15/1984, which limit the growth of irrigation areas; and Royal Decree 531/1992, on the control and rational usage of water resources. These systems have been widely adopted in the sector, not only due to the need for efficient water use, but also due to the improvement in yields and productivity obtained when controlling the expenditure on other factors, such as fertilizers. 


\section{José A. Aznar-Sánchez, Emilio Galdeano-Gómez and Juan C. Pérez-Mesa}

increased vigilance, the exploitation of controlled quarries and the progressive substitution of 'enarenado' (sand-covered crops) by soil-less or hydroponic systems. Different Rural Hygiene Plans have been implemented to improve the collection of many types of waste materials and their treatment, and have helped to reduce this problem (Gómez 2003, 137-9). It is also worth noting the growing awareness of the farmers regarding the necessity to maintain a clean environment, particularly as a result of the incorporation of biological control techniques and the treatment of pests in crops. The administration has also shown more awareness and has taken an active stance (Fundación Cajamar 2009, 13). The result of all the above is that many of the externalities pointed out previously are being solved, and there has been a gradual internalization of these environmental and territorial costs.

It should also be mentioned that since the early 2000s, the surface area dedicated to greenhouse production has hardly increased (Fundación Cajamar 2009). ${ }^{13}$ This has been due to several factors, such as the increase in the cost of inputs (for example, labour, seeds and plastics, the latter due to higher oil prices) and a trend towards stabilization of vegetable sale prices. This has led to a tendency towards greater investment in technology in the existing greenhouses, with a view to increasing crop productivity.

\section{Organization of Production and the Labour Process}

As mentioned above, the Almería model of intensive horticulture consists of small-scale farms. ${ }^{14}$ Over time, this predominant agrarian structure has changed to some extent, as the average size of the farms has increased, fomented by the accumulation of private capital and concomitant farmers' differentiation, together with technological improvements to greenhouses, allowing the management of more crops and land to cultivate. ${ }^{15}$ Nevertheless, relatively small land size is still characteristic of most farms, which helps them be predominantly family-run enterprises on land that the family owns.

Despite the small land size, most farms are characterized by a high degree of firm capitalization, which is also consistent with significant labour intensity. ${ }^{16}$ As opposed to other agricultural systems, intensive horticulture can operate with several crops a year, and so the growing season lasts longer, usually about nine months from September to May. Furthermore, the majority of the labour tasks in horticulture cannot be mechanized. Consequently, management of contract labour is an essential aspect of horticultural production in greenhouses, as the wages of labour constitute a significant cost factor (just over 35 per cent of total costs). Over the 1970s and 1980s, the labour factor was provided by the family members. Consequently, it can be said that this farming model has allowed farmers to increase substantially their standard of living since they became most part of the farming incomes. It has also allowed a homogenous distribution of incomes among the farmers of the area (Molina 2005, 17). From the 1990s, employment opportunities in the cluster of auxiliary activities that sprang up around intensive agriculture, the social and educational betterment of the children of greenhouse pioneers, and the increase in the surface area cultivated by each greenhouse owner, have all contributed to changing the labour features of the sector. The need to employ increasing numbers of wage workers has given rise to huge immigration into the regions where intensive agriculture was most practised (Sánchez 2005, 83-4).

13 The 26,000 ha of this whole sector, mentioned above, have remained practically constant.

14 In other Spanish areas with intensive agriculture under plastic, such as Murcia and Canarias, the average dimension is above 10 ha and labour is only external.

15 The average surface area of farming firms has grown from an average greenhouse of 1 ha in the mid-1980s to 2.4 ha at present.

16 On average, each hectare of greenhouse uses 560 days of labour, equivalent to 2.3 people working permanently. 


\section{Intensive Horticulture in Almería (Spain): A Counterpoint}

Besides having to employ non-family labour, farmers were also obliged to start introducing technological innovations in order to improve the quality of their produce and so meet the demand from their final markets. As a result, farmers found that they required active technical assistance and increasing levels of capital investment, but at the same time they were still running labour-intensive production systems. In the 1990s, the increase in the price of technological inputs was sharper than the increase in profit per hectare and so profit margins were reduced. In this new context, in order to remain competitive, family firms had to cut back on their major expense, which was also the one over which they had the greatest degree of control, namely contract labour (Ruiz 1995, 137). However, many owners were slow to shake off the habits acquired over the years when the employed wage workers and continued to rely heavily on manual labour (which horticultural production requires for certain practices). Thus, the rapid adaptation that occurred in the acquisition and handling of technology and marketing practices was not accompanied by changes in mentality regarding employees (Pumares 2003, 59). In addition to this, the family farming firms presented two structural problems: on the one hand, their small size meant that each farm needed few workers, and so it was difficult for them to contract immigrants in their country of origin and to organize their stay; on the other hand, labour requirements vary greatly throughout the season. ${ }^{17}$ Therefore, a major proportion of labour requirements are temporary and in some cases merely occasional, and the existence of an abundant, flexible and undemanding workforce (such as immigrant workers) has become a basic component in the maintenance of this system of accumulation. The specific legal requirements to contract non-EU immigrant workers were not suited to the characteristics of the agricultural labour market, as the administrative steps were highly inflexible. Despite this fact, many immigrants contemplated the possibility of working in the agricultural sector as a means of legalizing their situation in the country. ${ }^{18}$ This meant that on many occasions the farmer had to turn to undocumented (illegal) migrant labour (Pumares 2003, 58-62), which lacked the appropriate preparation.

The combination of all these factors has given rise to a system characterized by a high turnover of employees and a significant proportion of undocumented immigrants (many of them temporary workers in the sector, using the job as a preliminary step to travelling to other EU countries). The availability of immigrant labour helped to solve some of the sector's labour constraints but has also acted as a magnet for the arrival of new immigrants (both with and without their papers in order). Nevertheless, the different government regulations (Ministry of Labour and Social Services) regarding the immigrant population (Organic Law 4/2000 of 11 January 2000, and Royal Decree 2393/2004 of 30 December 2004) and stricter frontier controls have helped to reduce the proportion of undocumented immigrants and the uncontrolled arrival of foreign workers in Almería. In addition, in recent years the controls carried out by the Labour Inspection authorities have been more frequent and farmers have received high fines for irregular employment, meaning that there has been less illegal employment of immigrant workers without residence permits and employers have had to rethink how the labour market is organized. Moreover, from an economic point of view, a production model with a high turnover of workers is problematic, as a lot of time must be dedicated to training and re-training workers who need to become familiarized with tasks and take time to carry them out efficiently. Also, if the workforce is not stable, it is impossible for workers to become

17 Labour requirements were conditioned by seasonality in the productive cycle, intensity at certain given but intermittent times, the vegetative cycle of the plants and the strategies adopted by agricultural employers in the face of market fluctuations (Aznar and Sánchez 2000, 105-6).

18 This complex melting pot of farmers, migrant workers and administration, all with different motivations, has also occurred in places such as South Africa (Johnston 2007). 


\section{José A. Aznar-Sánchez, Emilio Galdeano-Gómez and Juan C. Pérez-Mesa}

specialized in given tasks and so improve productivity. From a social perspective, immigrant workers in precarious work conditions find it difficult to settle and become integrated in society, the precariousness of their lifestyle increases and social conflict may be fomented. ${ }^{19}$

In order to overcome this situation, many farmers have sought solutions based on implementing measures to make greenhouse work more attractive to documented workers (linking salaries to productivity, mechanizing the most strenuous tasks etc.), looking for mechanisms that provide job stability and specialization ${ }^{20}$ (Fundación Cajamar 2009, 6-7). Furthermore, several producer associations have put into practice campaigns to contract immigrant workers in their country of origin in order to guarantee the availability of a legal workforce. Looking to the future, the farmer must take a more business-like stance when organizing the labour process. Producer organizations must play a fundamental mediating role to coordinate and channel the demands of individual producers. In addition, the government must establish a system to manage the flows of immigrant workers more efficiently, in order to foresee requirements and channel job offers. Furthermore, the government should propose a viable alternative adapted to the particularities of the sector, which allows farmers to contract non-EU workers legally and predictably.

\section{Marketing and International Markets}

This sector has developed its own marketing structure, which has allowed it to concentrate considerable volumes of farming supply and to maintain constant mercantile activity, retaining an ever-greater part of the value added generated by this productive sector. In fact, the intensive evolution of intensive agriculture in Almería cannot be understood without taking into account the implementation of a modern marketing system, which has allowed the produce to be sold on international markets. Over the years, a structuring of distribution channels has been achieved following a local marketing model comprised of two methods, which both complement and compete against each other. First, there was local sale by means of an auction system (exchanges), and then came direct sale to consumer markets through distribution companies organized by the growers themselves (mainly cooperatives), which implied a vertical integration (Martínez-Carrasco 2004).

In the early years of the development of intensive agriculture in Almería, producers depended on marketing agents from outside the province, and so they were unable to know the marketing channels, final prices, quality standards and specificities of demand in the final markets. This dependence decreased gradually, first due to the creation of auction systems (so-called 'alhóndigas') ${ }^{21}$ and later because the farmers became involved in tasks of handling and marketing of the produce via cooperatives. Thanks to this model, practically all produce is currently marketed directly from Almería for both national and international markets. Apart from retaining more value added for the area and achieving better prices, the action of involving farmers in direct distribution has also allowed them to maintain direct contact with the markets, making them more inclined to favour innovation and adapt to the changing needs of demand (Molina 2002, 167-9).

\footnotetext{
19 We can find certain similarities with Mexican horticulture, where farm enterprises have achieved major progress in productivity but at the expense of their workers' salaries and living and working conditions (C. de Grammont and Lara 2010).

20 For example, some cooperatives have set up working teams to carry out specific tasks such as greenhouse maintenance. In other cases, women are taught to manipulate products and they are employed consistently in successive campaigns.

21 The 'alhóndigas' are centres of contracting at origin, in which the horticultural produce is acquired by marketing agents in auctions.
} 


\section{Intensive Horticulture in Almería (Spain): A Counterpoint}

During this stage the sector underwent a significant reorientation towards international markets. The continued improvement of local distribution channels has permitted rapid and constant incorporation of horticultural produce to the export market (Martínez-Paz et al. 2001; Pérez-Mesa 2007). Sales to international markets did not begin until the late 1970s, and in 1980 they only accounted for 9 per cent of production. From the second half of the 1990 s, $^{22}$ sales in foreign markets continued to rise to the point at which they had absorbed more than half of Almería's horticultural production (56.3 per cent in 2008). ${ }^{23}$ During this time, this province became the largest exporter of fresh vegetables in Spain, representing about 30 per cent of the national total in recent years. Also, exports of horticultural produce have been the nucleus of Almería's exports, representing over 80 per cent of provincial sales to foreign markets and almost 10 per cent of all Andalusian exports.

In the context of the current global food economy, one of the major challenges facing the sector is achieving a greater degree of the concentration of supply in this structure of numerous small firms. Despite the above-mentioned evolution of producer organizations for marketing purposes (e.g. cooperatives), which has allowed the supply to be concentrated and a relative degree of vertical integration, there is still an excessive number of marketing firms, which is an ever-greater weakness given the concentration of distribution. ${ }^{24}$ In view of this, since the early 1990s Almería's marketing firms have had to adapt to the way the distribution chains work and to provide them with the produce and services that they demand (particularly with the above-mentioned development of associated or cooperative entities). To date, the sector has responded well to these changes, but the large commercial chains have strengthened their position through processes of concentration and globalization, which have allowed them to continue increasing their bargaining power and demands to suppliers. This growing 'buyer drivenness' has not been offset by improved organization of production and marketing at origin, and so the producer/exporter is at a disadvantage that needs to be corrected (Pérez-Mesa 2007, 42-4). The distributors' greater market power is translated into better sales conditions for them and reduced margins for the producer. In view of this trend, Almería's marketing firms should carry out concentration processes in order to be able to satisfy the requirements of large-scale distribution (the need for great quantities, a wide range of products, guarantee of year-round supply, incorporation of services etc.) (Planells and Mir 2002, 125-9). It is a question of creating strong associated entities that have the capacity to cooperate and regulate production and to differentiate it from other produce in order to get profitable prices for the farmer and strengthen their niche in the market.

Another factor that may influence the future of this sector is the increasing competition in the markets. From the outset, Almería's intensive horticulture has been developed thanks to family investment and capital, with few or no subsidies. Despite Spain's eventual incorporation

\footnotetext{
22 Spain's entry into the European Economic Community did not result in a major increase in exports, due to the many conditions imposed on the fruit and vegetable sector by the Treaty of Adhesion; namely, applying an atypical transition period of 10 years during which Spain had to put up with the same reference prices as any non-member country. However, once the period of verification and adaptation to Community norms ended, the benefits to exports became apparent, and this was the moment in which Spain's integration really began, culminating in full membership on 1 January 1993 (Molina 2002, 166-7).

23 Exports of vegetables from Almería have increased from just over 80,000 tons in 1980 to over 1,660,000 in 2008 (Fundación Cajamar 2009, 9-10).

24 The power of retailers and their growing internationalization, as described by Weis (2007, 81), in 'the global food economy is becoming progressively less democratic as agro-input and agro-food transnational corporations appropriate a growing share of both control and surplus in agriculture', putting at risk the small farmers' chances of survival (see also, e.g., Friedmann 1993). This effect has also been seen over recent decades for the marketing processes in the horticultural sector, which have undergone a radical transformation due to the growth of the major retail distribution chains, in our case on the European scale (Galdeano 2003, 195).
} 


\section{José A. Aznar-Sánchez, Emilio Galdeano-Gómez and Juan C. Pérez-Mesa}

into the European Economic Community (EEC) in 1986, many restrictions were imposed on the sector over a ten-year transition period. It was not until the end of this period and the advent of the Common Market Organization of Fruit and Vegetables (EC - European Commission - Regulation 2200/96) that the first subsidies began to be granted, and even then they were relatively small (as tended to be the case for Mediterranean produce) and directed essentially at improving quality and developing environment-friendly practices. Thus, while for some crops (especially the continental ones such as cereals, dairy products, beef or sugar) and for some Spanish regions Community aid represents over 35 per cent of the value of the produce and of the farmers' income, in the fruit and vegetables sector they account for no more than 2 per cent (Pozancos 2002, 150); and in the specific case of Almería's agriculture subsidies they only account for 1.6 per cent of agricultural income (García 2005, 158). Nevertheless, this lack of support has also constituted an incentive for the sector to be market oriented, particularly towards exports to European countries. One of the principal factors in boosting and consolidating the sector was the access to an expanding market within a framework of commercial openness, and this was favoured by Spain's entrance into the EEC and the end of the transition period. To date, the access of produce from countries outside the European Union has been under strict control, allowing European (Almería) produce to enjoy a comparative advantage. However, in the international context a series of modifications is taking place and creating an ever more global and competitive market. On the one hand, the European market is actively opening up based on agreed multilateral commitments (World Trade Organization, WTO) and on the many bilateral and multilateral agreements and initiatives, particularly in the Mediterranean area (García and Mastrostefano 2002, 83-4). On the other hand, competitive conditions are likely to become considerably tougher due to the emergence of vegetableproducing countries that have major advantages regarding costs, which allow them to compete price-wise and which come into direct conflict with Almería's horticultural production due to the coincidence of products, final markets and exports schedules. ${ }^{25}$ For this sector, the legalization and the opening up of the European market will undoubtedly represent greater competition from imports from outside countries. In order to adapt to this new competitive scenario, it is necessary to maintain not only better marketing organization, as mentioned above, but also the high level of investments, in order to be able to differentiate one's produce with respect to new suppliers and to compete in terms of quality and incorporation of services. Furthermore, Almería's companies must start to consider global investments and the new opportunities that arise, as opposed to when a regional approach is adopted (Aznar 2007, 69-71). This strategy may give rise to winners and losers within the sector, according to their capacity for adaptation.

\section{Technological Innovation}

As indicated above, technological innovation played a fundamental role in the initial development of this sector, with the 'enarenado' technique and the plastic greenhouses. Later, the technological component maintained its contribution to development, allowing farming techniques to continue evolving thanks to the constant introduction of innovations geared towards growth, responding to the needs and peculiarities of the local area. The incorporation of new technology into farms during this period has been massive, substantially improving yields and allowing the average production per hectare to more than double, increasing from a little over 25 tons per hectare in 1975 to more than 64 in 2008. The use of greenhouses also allows

25 One paradigmatic example of this conflict is that of intensive horticulture in Morocco (Aznar 2006). 


\section{Intensive Horticulture in Almería (Spain): A Counterpoint}

greater precocity of crops and therefore the possibility of obtaining early harvests in comparison to the rest of Spain and Europe, supplying produce in the winter months without having to use costly heating systems as in other parts of Europe (mainly Holland). Furthermore, this increased yield has produced an improvement in quality, an extension of growing seasons and the harvest of two and up to three crops a year, which is known as 'crop forcing' (Tout 1990; Ferraro and Aznar 2008).

The constant incorporation of new technologies of ever-greater efficiency has imposed an increasing rate of technical sophistication in the handling of greenhouse crops. This results in a productive complex and dynamic system, which deals with vast amounts of labour and agro-chemical products of different kinds on a semi-artificial soil under the protection of polyethylene covering. Consequently, in reality this form of agricultural production is closer to models of 'industrial agriculture', based on great amounts of intermediate inputs and ever more sophisticated technology.

Skills and experience have played a fundamental role in the technological arena. On the one hand, it is important to note that the majority of the first settlers had prior experience in agricultural labour, particularly with horticultural and/or vine crops. Moreover, they were young and energetic, which made them more receptive to the incorporation of new farming techniques, which, in turn, drove them to participate in the constant improvements and create a favourable environment for technological innovation and its rapid and widespread implementation (García-Latorre et al. 2001). In addition, the generational renewal that is currently taking place with the incorporation of descendants of older farmers is helping to intensify this rejuvenation process by means of technological innovation. On the other hand, the constant incorporation of innovations, both in production processes and inputs, could not be understood without considering the role played by agricultural engineers and technicians. Almería is one of the areas with the highest density of workers dedicated to technical agronomic consulting, ${ }^{26}$ many of whom are self-employed, whereas others are employed by different enterprises (cooperatives, auxiliary industries etc.). They carry out a fundamental role in disseminating technical information to farmers via both formal and informal contacts with them (Ferraro and Aznar 2008, 368-9).

In addition, over this period the province of Almería has seen the emergence of research and development centres that are focusing their efforts towards meeting the needs of the sector and favouring the development of innovations (Pallarés-Barberá 2002). Some centres are public institutions (Andalusian Institute for Research and Training in Agriculture, Fisheries, Food and Ecological Production - IFAPA - and the University of Almería), others private (Las Palmerillas Experimental Station - founded by the Caja Rural Intermediterránea, Cajamar - and the Foundation for Auxiliary Technology in Agriculture, TECNOVA), and some are mixed (Innovation Centre of the Association of Horticultural Farmers and Exporters, COEXPHAL). Some have even become worldwide referents, as is the case of both the Las Palmerillas Experimental Station and the University of Almería, through the efforts of various research groups and its experimental farm. ${ }^{27}$ Furthermore, the collaboration among these centres is always growing,

\footnotetext{
26 According to the Colegio Oficial de Ingenieros Técnicos Agrícolas of Almería, in 2006 there was on average one technician for every 20 ha and every nine farmers. Moreover, the continuing growth in the number of professionals in this field over recent years has helped to increase the quality of the service provided, as each technician has to deal with a smaller number of hectares.

27 The University of Almería is taking part in the first 'Excellence Campus' for agrifoods in Spain, having been recently approved together with four other Andalusian universities (Córdoba, Jaén, Cádiz and Huelva). In addition, the University of Almería has created a Research Centre for Agrifood Biotechnology and another one for Biological Control.
} 


\section{José A. Aznar-Sánchez, Emilio Galdeano-Gómez and Juan C. Pérez-Mesa}

and the new Almería Science and Technology Park (PITA, in Spanish) aspires to become the central tool of the agro-industrial production system, drawing together companies, institutions and research centres connected to the cluster (Ferraro and Aznar 2008, 370-1).

The companies in the sector are collaborating more and more closely with the university and provincial research centres. Local companies linked to the supply sector, and other related sectors, are also becoming actively involved in applied research works. In addition, research centres maintain important information exchanges with companies and also disseminate the results of their research (Galdeano-Gómez et al. 2008). The results are excellent, especially in the technologies of production processes that can be adapted to the special conditions of the sector in this province. ${ }^{28}$

\section{The Formation of an Agro-industrial Cluster}

Agro-industrial linkages are a significant feature of Almeria's success story. In fact, one of the novel elements of the sector in Almería is the development of a major agro-industrial cluster around the production and marketing of vegetables. Almería's greenhouse horticulture is an intensive agricultural system that requires the consumption of many intermediate products of different kinds, which has given rise to a complex system of industrial relationships and services. In other words, alongside the importance of the intensive agriculture itself for the economic development of Almería, the generation of a great variety of industrial activities and services has become transcendental to contribute to diversify and develop the province's productive system.

At the end of the 1980s, most of the inputs used by Almería's intensive agriculture came from other Spanish provinces or countries with a more established tradition of horticulture, although some local manufacturing and supply companies were starting to appear. From then on, centres of production and distribution were set up in the province, as were local companies in the different sectors of the activities associated with intensive horticulture. Local private initiative has identified and set up most of the service activities (handling, marketing, transport, financial systems, IT services, agronomic assessment etc.). With regard to industrial activities, in some sectors the firms are mainly local ones (plastics, irrigation and fertigation, containers and greenhouses), and there is a growing number of local firms among those supplying the technological inputs (seeds, biological production, machinery and agro-chemical products) (Aznar-Sánchez and Sánchez-Picón 2010, 177-9). ${ }^{29}$ As a result of this evolution, a complex system of industrial activities and services has arisen, grown and diversified, all revolving around the greenhouse farming that is the base of the current agro-industrial cluster (Figure 3).

This cluster is experiencing constant dynamism, as is demonstrated by its evolution, performance, the number of companies, the creation of jobs and sales to international markets. All this has helped the sector to achieve the following significant figures: 14,000 enterprises, with an income of 8.6 billion euros, 50,000 employees and an export value of 1.7 billion euros (Ferraro and Aznar 2008, 372-4). However, while these figures are quite significant, the most notable

28 Although many of the innovations are of incremental nature and are not protected, 57 patents were requested by firms in the auxiliary industries of the productive system linked to intensive agriculture in Almería between 2001 and 2007, placing it at the forefront of Andalusia, accounting for 31 per cent of Andalusian patents requested by the agrarian industry (Fundación Tecnova 2009, 15-7). The Spanish Patents Office recorded 43 patents from the University of Almería between 2000 and 2008, most of which were linked to the agricultural sector.

29 Therefore, the endogenous and local nature of this agro-industrial cluster is noteworthy. As mentioned above, there has been little direct foreign investment, except in the case of seed suppliers (mostly Dutch and French firms) that have set up some branches in the sector, also using the location for experimental purposes. In recent years, however, local firms have also been set up, making use of the technologies best adapted to the requirements of this sector as far as inputs are concerned. 
Figure 3 Production linkages in the agro-industrial cluster of Almería

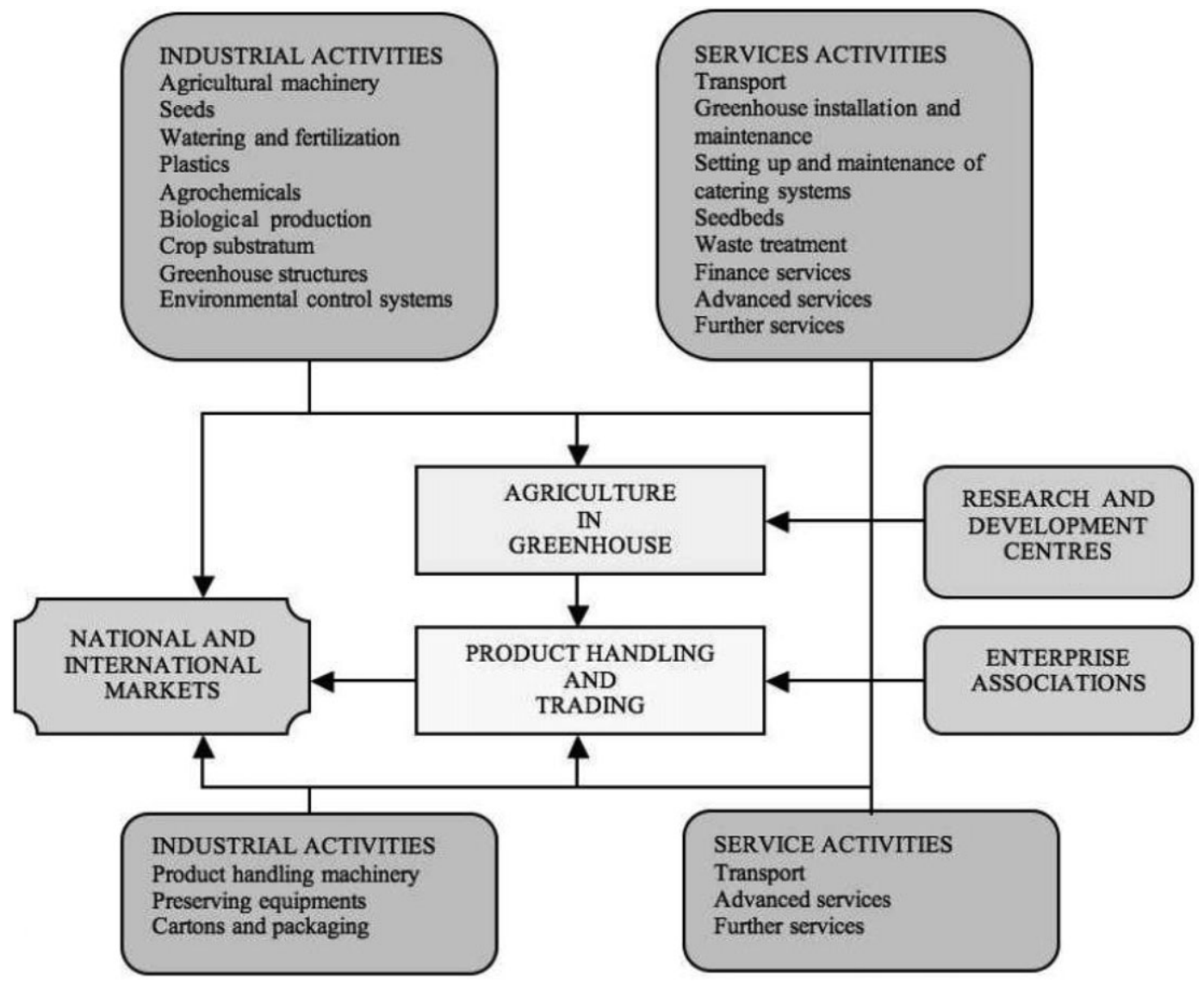

Source: The authors.

aspects are the production links established between the different sectors that make up the cluster; that is, the whole is more than the sum of its parts. In this way, apart from the production links of secondary industries and services with primary activities which justify their creation (agricultural, marketing and packing activities), these industries and services have been creating a network of business and cooperative relationships that give the cluster strength and unification.

The existence of this cluster provides added competitive advantages to Almería's intensive agriculture sector, as they can count on many local suppliers of all types of components, machinery and specialized services. The intensive competition, the high number of potential customers and the creation of new companies have contributed to the creation of a climate of change and improvement in which the competing companies become allies in the innovation process. The existence of nearby suppliers reduces costs and delays in receiving supplies, as well as reducing the risk, due to both the variety of supply and the ease of maintenance and repairs. In addition, the geographical proximity of clients and suppliers encourages working relationships and strengthens both sides (Aznar 2006, 273-5). 


\section{José A. Aznar-Sánchez, Emilio Galdeano-Gómez and Juan C. Pérez-Mesa}

\section{CONCLUSIONS}

Unlike most studies, which tend to identify the minor role of the agrarian sector in stimulating economic growth in European rural regions, this paper highlights the exceptional role of this sector in the case of Almería. It is unique in the sense that the economic development of the region has been spurred by the agricultural sector. Traditionally, economic modernization has gone hand in hand with industrial development, making it hard to comprehend the structural change in Almería based on a 'traditional' sector such as agriculture.

The explanation lies in the peculiarities of Almería's intensive horticulture, considering the social, technological and economic aspects. On the one hand, we are dealing with a model of industrial agriculture based principally on relatively small family-run firms, which has allowed a quite equally proportioned redistribution of the income generated in the sector across a wide segment of the population of Almería. On the other hand, this type of agriculture is built on a technological system that is institutionally complex and dynamic, closer to the concept of an agricultural 'factory' than to traditional horticultural production, due to the high capital requirements, the high content productive inputs, and the scale of labour use and technological support on which it is based. The value added that it generates is far greater than that of 'traditional' agricultural techniques as a result of the incorporation of cutting edge technology and the intensive use of intermediate inputs. Moreover, it is mostly aimed at distant markets, and so it requires qualified inputs and services for distribution and sales. In addition, it has given rise to major positive externalities, with the creation of a number of local companies responsible for supplying goods and services required for the production and marketing. For all of these reasons, intensive horticulture has played the same modernizing role in Almería as basic industries or consumer goods industries have in other areas or countries.

Analysis of the processes of change that Almería's intensive horticulture sector has undergone since the 1970s confirms that it has changed from a model based on absolute advantages to one characterized by its competitive advantages. At first, the sector was propelled by an initial advantage founded on the availability of a series of privileged natural resources that allowed production during times of the year when it was not possible in other European countries. However, over time a new series of dynamic advantages were generated as a result of the presence of certain advanced factors (specialized personnel, local know-how, research and development centres, training centres etc.), the accumulation of experience, as well as technology and production innovations - all functioning within a favourable institutional framework, and accompanied by a flexible local production system. At present, Almería's horticultural sector constitutes a system with great capacity for innovation and improvement of its competitiveness. This is possible thanks to the generation of tangible and intangible assets, such as: intense internal competition; competitive local suppliers; an appropriate environment for investment and the creation of new companies; an extreme geographical concentration, leading to economies of agglomeration; highly motivated and dedicated participants in the sector; swift improvement of factors of production; as well as efficient formal and informal methods of communication among members in the sector. Moreover, a series of intangible assets has also arisen over the years (local know-how, networking etc.) that provide the sector with great strength, competitive power and the flexibility with which to face new challenges, particularly in international markets. Nevertheless, certain aspects of this system must be improved and certain weaknesses that may limit its growth rate and future viability must be overcome. Among other problems that are being tackled, we should mention suitable management of contract labour, further reduction of the environmental impacts and improvements to the territorial 


\section{Intensive Horticulture in Almería (Spain): A Counterpoint}

organization. And as an essential challenge we should mention tackling the problem of dispersion of supply in marketing activity in a context of food globalization.

Overall, this study provides additional elements for the debate on the paradigm of rural development in Europe and the guidelines for policies or rural development. Over recent decades, support for multifunctionality and diversification has predominated, but the case of Almería highlights the fact that backing agriculture may be a viable alternative means of development in some European rural regions that have specialized in a competitive and dynamic agrifood sector. The boom in intensive agriculture in Almería constitutes an example of endogenous development based on the effective use of natural resources, considerable business initiative and local productive organization, and on the creation and diffusion of innovative productive systems. All of these have led to accumulation of capital and know-how, together with a high degree of competitiveness in the national and international agrifood context. In short, the Almería success story appears to be a counterpoint to current European rural development strategies that consider fomenting agriculture a mistake.

\section{REFERENCES}

Aznar, J.A., 2006. La competencia entre la horticultura intensiva de Marruecos y España. Navarra: Thomson-Civitas.

Aznar, J.A., 2007. 'El proceso de internacionalización comercial de la horticultura intensiva almeriense'. Revista de Estudios Empresariales, 1: 55-72.

Aznar, J.A. and A. Sánchez, 2000. 'Inmigración en tierra de emigración: el caso de Almería'. Economistas, 86: 97-115.

Aznar-Sánchez, J.A. and A. Sánchez-Picón, 2010. 'Innovación y distrito en torno a un "milagro”: la configuración del sistema productivo local de la agricultura intensiva de Almería'. Revista de Historia Industrial, 42: 157-93.

Baldock, D., J. Dwyer, P. Lowe, J.E. Petresen and N. Ward, 2001. The Nature of Rural Development: Towards a Sustainable Integrated Rural Policy in Europe. London: Institute for European Environmental Policy (IEEP).

Brouwer, F., 2004. Sustaining Agriculture and the Rural Environment: Governance, Policy and Multifunctionality. Advances in Ecological Economics Series. Cheltenham: Edward Elgar.

Bryden, J.M., 2003. Rural Development Situation and Challenges in EU25. Salzburg: Keynote Speech, EU Rural Development Conference.

Bryden, J.M. and K. Hart, eds, 2004. A New Approach to Rural Development in Europe: Germany, Greece, Scotland, and Sweden. Lewiston: Mellen Studies in Geography (9). Queenston, Lampeter: The Edwin Mellen Press.

Buchenrieder, G., J. Möllers, K. Happe, S. Davidova, L. Fredrikson, A. Baley, M. Gorton, D.A. Kancs, J. Swinnen, L. Vranken, C. Hubbard, N. Ward, L. Juvancic, D. Milczarek and P. Mishev, 2007. Conceptual Framework for Analysing Structural Change in Agricultural and Rural Livelihoods. Halle (Saale): IAMO Discussion Paper 113.

C. de Grammont, H. and S.M. Lara, 2010. 'Productive Restructuring and 'Standardization' in Mexican Horticulture: Consequences for Labour'. Journal of Agrarian Change, 10 (2): 228-50.

Campra, P., M. Garcia, Y. Canton and A. Palacios-Orueta, 2008. 'Surface Temperature Cooling Trends and Negative Radiative Forcing due to Land Use Change toward Greenhouse Farming in Southeastern Spain'. Journal of Geophysical Research Atmospheres, 113: D18109, doi:10.1029/2008JD009912.

Cloke, P.J., 1997. 'Country Backwater to Virtual Village? Rural Studies and the Cultural Turn'. Journal of Rural Studies, 13 (4): 367-75.

Colino, J. and J.M. Martínez, 2002. 'El agua en la agricultura del sureste español: productividad, precio y demanda'. Mediterráneo Económico, 2: 199-221.

Consejería de Agricultura y Medio Ambiente, 1991. Recursos naturales y crecimiento económico en el 'Campo de Dalías'. Sevilla: Agencia de Medio Ambiente.

Cotec, 2009. Documento sobre oportunidades tecnológicas. Invernaderos de plástico. Madrid: Fundación Cotec para la Innovación Tecnológica.

Council Regulation (EC) No. 1698/2005 of 20 September 2005 on support for rural development by the European Agricultural Fund for Rural Development (EAFRD).

Downward, S.R. and R. Taylor, 2007. 'An Assessment of Spain's Programa AGUA and its Implications for Sustainable Water Management in the Province of Almería, Southeast Spain'. Journal of Environmental Management, 82 (2): 277-89.

Dwyer, J., R. Eaton, G. Beaufoy, H. Buller and N. Ward, 2002. Appraisal of Flexibility under ERDP and Comparison with Approaches in Other Countries. Report to the North West Development Agency, June. 


\section{José A. Aznar-Sánchez, Emilio Galdeano-Gómez and Juan C. Pérez-Mesa}

European Commission, 2007a. Agriculture in the European Union - Statistical and Economic Information 2006. Brussels: Directorate-General for Agriculture and Rural Development.

European Commission, 2007b. The Importance and Contribution of the Agri-food Sector to the Sustainable Development of Rural Areas. Brussels: Directorate-General for Agriculture and Rural Development.

Ferraro, FJ., dir., 2000. El sistema productivo almeriense y los condicionamientos hidrológicos. Madrid: Civitas.

Ferraro, FJ. and J.A. Aznar, 2008. 'El distrito agroindustrial de Almería: un caso atípico'. Mediterráneo Económico, 13: 353-82.

Friedmann, H., 1987. 'International Regimes of Food and Agriculture since 1870'. In Peasants and Peasant Societies, ed. T. Shanin, 258-76. Oxford: Blackwell.

Friedmann, H., 1993. 'The Political Economy of Food: A Global Crisis'. New Left Review, 197: $29-57$.

Friedmann, H., 2005. 'From Colonialism to Green Capitalism: Social Movements and Emergence of Food Regimes'. In New Directions in the Sociology of Global Development, eds F.H. Buttel and P. McMichael, 227-64, Research in Rural Sociology and Development, II. Amsterdam: Elsevier JAI.

Friedmann, H. and McMichael, P., 1989. 'Agriculture and the Estate System: The Rise and Fall of National Agricultures, 1870 to the Present'. Sociologia Ruralis, 29 (2): 93-117.

Fundación Cajamar, 2009. Análisis de la campaña hortícola de Almería. Almería: Cajamar.

Fundación Tecnova, 2009. Tecnometro. Observatorio económico y de innovación de la industria auxiliar de la agricultura. Almería: Fundación Tecnova.

Galdeano, E., 2003. 'The Role of Co-operatives in the Competitiveness of the Horticultural Sector'. Journal of Co-operative Studies, 36 (3): 190-212.

Galdeano, E., 2005. 'An Inverse Demand Analysis with Introduction of Quality Effects: An Application to Consumption of Fruit and Vegetables'. Agricultural Economics, 33: 163-77.

Galdeano, E. and J. De Pablo, 1999. 'La agricultura intensiva en el sureste español: análisis de los determinantes de su desarrollo’. Economistas, 81: 91-103.

Galdeano-Gómez, E., J. Céspedes-Lorente and J. Martínez-del-Río, 2008. 'Environmental Performance and Spillover Effects on Productivity: Evidence from Horticultural Firms'. Journal of Environmental Management, 88: 1552-61.

García, R., 2005. 'El sector agrario’. In La economía de la provincia de Almería, dir. J. Molina, 153-208. Almería: Cajamar.

García, T. and M. Mastrostefano, 2002. 'Algunas reflexiones sobre los retos del sector europeo de las frutas y hortalizas'. Mediterráneo Económico, 2: 83-99.

García-Latorre, J., J. García-Latorre and A. Sánchez-Picón, 2001. 'Dealing with Aridity: Socio-economic Structures and Environmental Changes in an Arid Mediterranean Region'. Land Use Policy, 18: 53-64.

Garzon, I., 2005. Multifunctionality of Agriculture in the European Union: Is There Substance behind the Discourse's Smoke? Working paper, Institute of Governmental Studies, University of California at Berkeley, CA.

Gómez, D., 2003. La horticultura en Almería. Bases para un Plan de Ordenación Territorial y Gestión Medioambiental. Almería: Cajamar.

Hassapoyannes, K., I. Daskalopoulou and N. Petrou, 1998. 'An Introduction to Different Conceptualisations of Endogenous Rural Development'. In Endogenous Rural Development in the Mediterranean Region, eds E., Stamataki and C. Clapan. Chania: CIHEAM-IAMC. Cahiers Options Mediterraneennes, 30: 1-9.

INE, Instituto Nacional de Estadística, 2008. Estadísticas. Madrid: INE.www.ine.es

Johnston, D., 2007. 'Who Needs Immigrant Faro Workers? A South African Case Study'. Journal of Agrarian Change, 7 (4): 494-525.

Knickel, K. and H. Renting, 2000. 'Methodological and Conceptual Issues on the Study of Multifunctionality and Rural Development'. Sociologia Ruralis, 40 (4): 512-28.

Losch, B., 2004. 'Debating the Multifunctionality of Agriculture: From Trade Negotiations to Development Policies by the South'. Journal of Agrarian Change, 4 (3): 336-60.

Lowe, P., J. Murdoch, T. Marsden, R. Munton and A. Flynn, 1993. 'Regulating the New Rural Spaces: The Uneven Development of Land'. Journal of Rural Studies, 9 (3): 205-22.

Marsden, T., J. Banks and G. Bristow, 2002. 'The Social Management of Rural Nature: Understanding Agrarian-based Rural Development'. Environment and Planning A, 34: 809-25.

Martínez-Carrasco, F., 2004. 'Selection of Marketing Channels by Intensive Horticultural Crop Growers in Almería'. Spanish Journal of Agricultural Research, 1: 27-34.

Martínez-Paz, J., F. Martínez-Carrasco and R. Dios-Palomares, 2001. 'Analysis of the Evolution of Protected Horticulture in Almeria Area: Cycles, Structure and Growth'. Acta Horticulture, 559: 713-18.

McMichael, P., 2009. 'A Food Regime Genealogy'. Journal of Peasant Studies, 36 (1): 139-69.

Molina, J., 2002. 'La comercialización en destino para el producto hortícola fresco'. In España, huerta de Europa, coord. F. Camacho Ferre, 166-73. Madrid: Ministerio de Agricultura, Pesca y Alimentación. 


\section{Intensive Horticulture in Almería (Spain): A Counterpoint}

Molina, J., 2005. 'Claves para la interpretación del modelo económico de la provincia de Almería'. In La economía de la provincia de Almería, dir. J. Molina, 13-41. Almería: Cajamar.

Mota, J.F., J. Peñas, H. Castro and J. Cabello, 1996. 'Agricultural Development vs. Biodiversity Conservation: The Mediterranean Semiarid Vegetation in El Ejido (Almería, Southeastern Spain)'. Biodiversity and Conservation, 5 (12): 1597-617.

Pallarés-Barberá, M., 2002. 'Enterprise Embeddedness and Industrial Innovation in Spain: and Overview'. In Embeddedness Enterprise and Social Capital, eds M. Taylor and S. Leonard, 113-25. Aldershot: Ashgate.

Pausewang, S., 1995. "Productionism” or "Sustainability", "Subsistence” or "Market Adaptation”. Social Consequences of Different Concepts for Agricultural Life on Family Farms in Remote Areas in Poor and Rich Societies'. Paper presented at the XVI Congress of the European Society for Rural Sociology, Prague.

Pérez-Mesa, J.C., 2007. 'Should Almería (Spain) Have to Worried, Thinking That Their Tomato Export is Currently Affected by International Competition?' Agricultural Economics Review, 8 (2): 42-54.

Planells, J. and J. Mir, 2002. 'La agroexportación ante la nueva distribución alimentaria'. Mediterráneo Económico, 2: 124-39.

Potter, C., 2004. 'Multifunctionality as an Agricultural and Rural Policy Concept'. In Sustaining Agriculture and the Rural Environment: Governance, Policy and Multifunctionality, ed. F. Brouwer, 15-35. Cheltenham: Edward Elgar.

Pozancos, J.M., 2002. 'Los retos de futuro del sector hortofrutícola español'. Mediterráneo Económico, 2: 140-58.

Pumares, P., 2003. 'El papel de Almería en la inmigración. Implicaciones de un modelo productivo en cuestión'. Paralelo 37, 18: 53-67.

Ray, C., 2001. Culture Economies. Newcastle: CRE Press.

Ruiz, P., 1995. 'Inmigración y mercado laboral en la horticultura forzada almeriense. Una aproximación'. Demófilo, 15: $135-54$.

Sánchez, A., 2005.'De frontera a milagro. La conformación histórica de la economía almeriense'. In La economía de la provincia de Almería, dir. J. Molina, 43-85. Almería: Cajamar.

Suchacek, J. and J. Malinovsky, 2007. Regional Development in Transitional Economies after 1989: Reformation or Deformation?. Paper presented at the 47th Congress of the European Regional Science Association, Paris.

Terluin, I.J., 2003. 'Differences in Economic Development in Rural Regions of Advanced Countries: An Overview and Critical Analysis of Theories'. Journal of Rural Studies, 19: 327-44.

Terluin, I.J. and J.H. Post, eds, 2000. Employment Dynamics in Rural Europe. Wallingford: CABI Publishing.

Tout, D. (1990). 'The Horticulture Industry of Almería Province, Spain'. The Geographical Journal, 156 (3): $304-12$.

United Nations Environment Programme (UNEP), 2005. One Planet, Many People: Atlas of Our Changing Environment. Nairobi: UNEP.

van der Ploeg, J., D. Renting, H. Brunori and K. Knickel, 2000. 'Rural Development: From Practices and Policies towards Theory'. Sociologia Ruralis, 40 (4): 391-408.

van Huylenbroeck, G. and G. Duran, eds, 2003. Multifunctional Agriculture: A New Paradigm for European Agriculture and Rural Development. Aldershot: Ashgate.

Ward, N., J. Atterton, K. Tae-Yeon, P. Lowe, J. Phillipson and N. Thompson, 2005. Universities, the Knowledge Economy and the 'Neo-endogenous Rural Development'. Centre of Rural Economy, Newcastle: Newcastle University.

Weis, T., 2007. The Global Food Economy: The Battle for the Future Farming. London: Zed Books.

Yin, R., 1989. Case Study Research: Design and Methods. London: Sage. 